\title{
Consumer awareness and use of baby care products with special reference to baby diapers
}

\author{
KALINDRI VERMA AND MEENU SRIVASTAVA
}

Received: 24.03.2017; Revised: 03.05.2017; Accepted: 19.05.2017

See end of the paper for authors' affiliations

\section{KALINDRI VERMA}

Department of Textiles and Apparel Designing, College of Home Science, Maharana Pratap University of Agriculture and Technology, UDAIPUR (RAJASTHAN) INDIA
ABSTRACT : With increased consumer awareness about health and hygiene for personal safety in view of harmful effects of chemicals used in textile processes and products, emphasis on use of herbal products has been increasing day by day. Health friendly baby care products are more in demand to take care of baby's sensitive skin and avoid common skin problems. The present exploratory study was conducted in Udaipur city of Rajasthan on 50 mothers of young babies below three years of age, using structured interview schedule. Findings revealed that majority of the respondents had good knowledge about baby care products and opined that these products used to give satisfactory performance in use but at the same time found them quite expensive to use.

KEY WORDS: Consumer, Awareness, Use, Baby, Care, Product, Diaper

- HOW TO CITE THIS PAPER : Verma, Kalindri and Srivastava, Meenu (2017). Consumer awareness and use of baby care products with special reference to baby diapers. Asian J. Home Sci., 12 (1) : 243-249, DOI: 10.15740/HAS/AJHS/12.1/243-249. 